\title{
Development and initial validation of the parent acceptable symptom state in juvenile idiopathic arthritis (JIA)
} G Filocamo*1, B Schiappapietra ${ }^{1}$, S Magni Manzoni'2, S Lanni ${ }^{2}$, N Solari1, S Viola ${ }^{1}$, A Pistorio ${ }^{1}$, N Ruperto ${ }^{1}$, D Tani ${ }^{1}$, A Martini ${ }^{1}$ and A Ravelli ${ }^{1}$

Address: ${ }^{1}$ IRCCS G Gaslini, Genova, Italy and ${ }^{2}$ IRCCS Pol San Matteo, Pavia, Italy

* Corresponding author

from $15^{\text {th }}$ Paediatric Rheumatology European Society (PreS) Congress

London, UK. 14-17 September 2008

Published: 15 September 2008

Pediatric Rheumatology 2008, 6(Suppl I):PII7 doi:10.II86/I546-0096-6-SI-PII7

This abstract is available from: http://www.ped-rheum.com/content/6/SI/PII7

(c) 2008 Filocamo et al; licensee BioMed Central Ltd.

\section{Background}

The parent acceptable symptom state (PASS) constitutes the symptom threshold beyond which parents consider their child' health status as satisfactory. The PASS represents an ambitious target for disease management.

\section{Objective}

To devise and validate the PASS in patients with JIA.

\section{Methods}

369 parents completed a multidimensional questionnaire (the JAMAR), including Juvenile Arthritis Functionality Scale (JAFS) (score 0-30), Pediatric Rheumatology Quality of Life (PRQL) questionnaire (score 0-30) and traditional JIA outcome measures, and stated whether they considered their children's status satisfactory or not. PASS thresholds were estimated based on parent opinion and targeting the $75^{\text {th }}$ percentile of cumulative distribution. Stepwise logistic regression was used to assess contributors to PASS. PASS was validated by analyzing proportions of patients who were judged by parent or physician in remission, flare or continued activity.

\section{Results}

$72.9 \%$ of parents reported their children being in PASS (table 1).

\section{Conclusion}

We devised the PASS for JIA. The PASS demonstrated good validity by discriminating strongly between patients in remission or active disease. 
Table I: The PASS threshold

\begin{tabular}{llllllll}
\hline & Parent global & Parent pain & JAFS & PRQL & MD global & Active joints & Limited joints \\
\hline $75^{\circ}$ centile & 2 & 1.5 & 1 & 4 & 1.5 & 1 & 1 \\
\hline
\end{tabular}

Parent global (OR 4.6), PRQL (3.9), JAFS (4.0), MD global (2.6) and CRP (3.9) were the strongest contributors of PASS in logistic regression analysis (AUC: 0.92). Among patients judged in remission, flare or continued activity by the parent and physician, the percentage of those in PASS was 98 , 46 and $49(p<0.000 I)$, and 93,57 and $27(p<0.000 I)$, respectively.

Publish with Biomed Central and every scientist can read your work free of charge

"BioMed Central will be the most significant development for disseminating the results of biomedical research in our lifetime." Sir Paul Nurse, Cancer Research UK

Your research papers will be:

- available free of charge to the entire biomedical community

- peer reviewed and published immediately upon acceptance

- cited in PubMed and archived on PubMed Central

- yours - you keep the copyright 